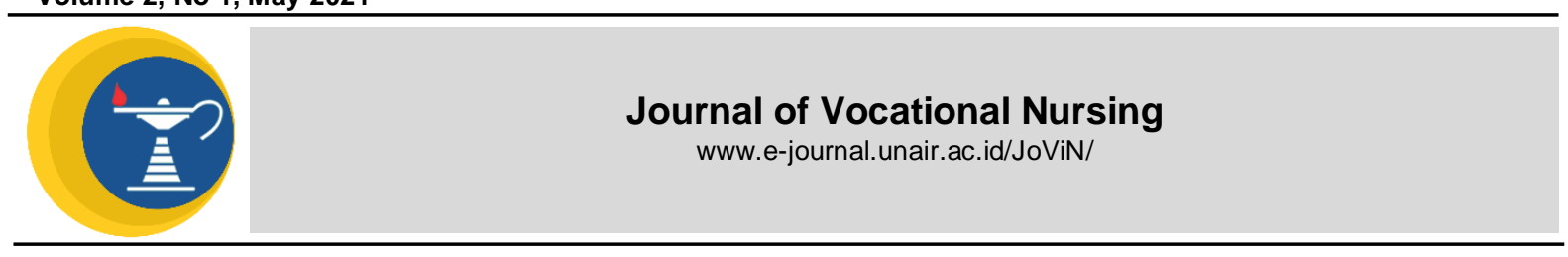

\title{
RELATIONSHIP LEVEL OF PARENTAL KNOWLEDGE ABOUT THE FUNCTION OF PLAYING WITH THE PROVISION OF APE (EDUCATIONAL GAME TOOLS) CHILDREN AGED 4-6 YEARS IN BALONG TUNJUNG VILLAGE, BENJENG DISTRICT, GRESIK
}

\author{
Emuliana Sulpat and Fitria Listianingsih \\ Faculty of Vocational Studies, Universitas Airlangga \\ Akademi Keperawatan Pemkab Gresik
}

\section{A BSTRACT}

Introduction: Play is an activity where the child can perform or practice skills, express thoughts, be creative, prepare to play and behave maturely, the results of a preliminary study in Benjeng 50 parental (64.70\%) do not know the function of play for children. The research objective is to determine the relationship between the level of parental knowledge and the provision of APE. Methods: The design of this study was a correlation study with a Cross Sectional approach, with all parent populations of 34 respondents, a sample of 20 respondents. Sampling using simple random sampling technique, data taken using questionnaire and observation sheets, then analyzed by spearman test with a significance level a $\alpha=$ 0.05. Results: The results showed that (50\%) of respondents had a moderate level of knowledge about the function of play and (65\%) respondents gave APE. The statistical test result obtained $r s=0,499$ and $p=0,025$, where $p>0,05$.

Conclusion: This study is a relationship between the level of knowledge of parents about the function of play and the provision of APE, in Balong Tunjung Village, Benjeng , Gresik.

\author{
ARTICLE INFO \\ Received March 3, 2021 \\ Accepted May 29, 2021 \\ Online May 31, 2021 \\ *Correspondence: \\ Emuliana Sulpat \\ *Email: \\ Emuliana.sulpat@vokasi.unair.ac.id
}

Keywords:

Knowledge Level, Play Function, Educational Game Tools

\section{INTRODUCTION}

Children and play are two things that are almost inseparable from each other. For children playing is all children's activities including work, pleasure and is a method of how they know the world (Soetjiningsih, 1995). Playing for children has a lot of meaning in its development. Because through playing many advantages are obtained, not only to the physical growth of the child, but also to the mental and social development of the child. In choosing a game tool as a means of stimulation of children's development, should be chosen play tools that not only please the child but should also be useful in optimizing their growth (Soetjiningsih, 1995). Along with the rapid development of technology, many game tools are produced by toy factories that allow children to choose which toys they want even though they are not necessarily appropriate for their age. In Balong Tunjung Village, mothers often only give toys as long as the child is happy but the mother never sees the benefits of the toy for her child. For example: PS (Plays Station).

Based on the data collected in Balong Tunjung Village, Benjeng Sub-district, Gresik on October 25, 2011, parents who have children aged 4-6 years old there are as many as 51 children. After the interview was obtained 33 people $(64.70 \%)$ who do not know the function of play for children and 18 people $(35.29 \%)$ say know the function of play for the child.

There are many factors that affect the development of children, one of which is the selection of educational game tools. In the use of educational game tools are found in the community do not understand the type of game because parents buy games regardless of the type of usefulness that is able to develop such aspects, so sometimes the price is expensive but not in accordance with the age of the child (Alimul, 2008). Choosing toys for children is easy to difficult, especially those circulating in 
the market of various types. Ideally children are introduced to various types of toys, both old and new. The benefit is to educate the child to be able to choose and distinguish what he needs. But what is happening in today's society is the habit of parents who choose toys for their children at a high price but after arriving home the toys are only stored in cupboards. Many parents also choose a type of toy that does not suit the child's age. In addition, in buying toys parents do not consider whether the toy is liked by the child or not, but what parents think is good directly bought. For example, game tools that are too difficult to frustrate children and vice versa if it is too easy will make children bored (Ngastiyah, 2005). From the description above we can know that in the selection of educational game tools (APE) is very useful for the development of children.

Choosing the right play tool according to the child's age is a simple but very useful way in helping to stimulate the child's development both physical, language, cognitive, and social aspects of the child. Therefore, parents should provide a chance to play and provide toys. Toys do not need to be purchased expensively, but can be made from ordinary / simple materials (Ngastiyah, 2005). In choosing a game parents should pay attention to each child, so that the child can grow and develop according to his age. In addition, the cultural background, gender, and health status and environment are things that should not be ignored in determining the type of game. Parents and children can choose toys together, but it should be remembered that the game tool should be safe for the child (Supartini, 2004). In order for our children to remain comfortable in playing, parents should be smarter in choosing play tools for their children, especially Educational Game Tools (APE), because in playing children need a variety of game tools and do not have to choose expensive ones, so that if the child is bored of games one can choose the other game (Soetjiningsih, 1995).

\section{MATERIALS AND METHODS}

In this study, researchers used correlational analytical design with cross sectional approach where the type of research that emphasizes the measurement time or observation of independent and dependent variable data only once at a time (Nursalam, 2008). In this study, the population is all parents who have children aged 4-6 years in Balong Tunjung Village, Benjeng Sub-district, Gresik as many as 34 respondents. In this study, samples were taken from some parents who had children aged 4-6 years who met the inclusion criteria of 20 respondents. The inclusion criteria in this study are mothers who have children aged 4-6 years, can read writing, are healthy physically and spiritually, and live with their children and are willing to be researched.

In this study using simple random sampling technique. In this study which is an independent variable is the level of knowledge of parents about the function of play. Dependent variable in this study is the administration of APE (Educational Game Tool) in children aged 4-6 years. The instrument in this study is to use questionnaires and observations in the form of closed questions.

\section{RESULTS}

Table 1. Demographics of respondent data shows that out of 20 respondents, almost half of respondents aged 31-35 years as many as 8 respondents (40\%), most respondents as housewives as many as 12 respondents $(60 \%)$, almost half of respondents educated Sample /equivalent as many as 9 respondents (45\%), half of respondents have a moderate level of knowledge as much as 10 respondents $(50 \%)$, and most of the respondents provide APE (Educational Game Tools) as many as 13 respondents (65\%).

\begin{tabular}{llcc}
\hline Characteristics & Indicators & $\begin{array}{c}\text { Number of } \\
\text { Respondents }\end{array}$ & Percentage (\%) \\
\hline Age & 16-20 years old & 0 & 0 \\
& $21-25$ years old & 5 & 25 \\
& $26-30$ years old & 6 & 30 \\
& $31-35$ years old & 8 & 40 \\
Job & 35 years old & 1 & 5 \\
& Housewives & 12 & 60 \\
& Farmers & 4 & 20 \\
& Self employed & 2 & 10 \\
& Civil Servants & 0 & 0
\end{tabular}


Private

No School

SD/equivalent

Junior High School /equivalent

High school/equivalent

Academies/colleges

Level of Knowledge Low

Are

High

APE (Educational Game Tool)
2

10

\begin{tabular}{llcc} 
Education & No School & 0 & 0 \\
& SD/equivalent & 4 & 20 \\
& Junior High School /equivalent & 9 & 45 \\
& High school/equivalent & 5 & 25 \\
Level of Knowledge & Academies/colleges & 2 & 10 \\
& Low & 3 & 15 \\
& Are & 10 & 50 \\
APE (Educational & High & 7 & 35 \\
Game Tool) & Given & 13 & 65 \\
& Not given & 7 & 35 \\
\hline
\end{tabular}

Table 2 The distribution shows from 20 respondents obtained half of respondents have a moderate level of knowledge as much as 10 respondents (50\%) which provided APE as many as 7 respondents (70\%) and who did not provide APE as many as 3 respondents $(30 \%)$, The results of the analysis to answer the research hypothesis with spearman rank test in SPSS with $\alpha=$ 0.05 obtained results $\rho=0.025$ ie $\rho<\alpha(0.025<0.05)$ so it can be explained that $\mathrm{H} 1$ is accepted which means that there is a relationship of the level of knowledge of parents about the function of playing with the provision of APE (Educational Game Tools) in children aged 4-6 years in Balong Tunjung Village, Benjeng Sub-district, Gresik.

\begin{tabular}{lcccccc}
\hline \multirow{2}{*}{$\begin{array}{l}\text { Level of } \\
\text { Knowledge }\end{array}$} & \multicolumn{2}{l}{ APE (Educational Game Tool) } & & Frequency & Percentage \\
\cline { 2 - 5 } & Given & Percentage & Not given & Percentage & & \\
\hline Low & 0 & $0 \%$ & 3 & $100 \%$ & 3 & $100 \%$ \\
Are & 7 & $70 \%$ & 3 & $30 \%$ & 10 & $100 \%$ \\
High & 6 & $86 \%$ & 1 & $14 \%$ & 7 & $100 \%$ \\
\hline Amount & 13 & $65 \%$ & 7 & $35 \%$ & 20 & $100 \%$ \\
\hline
\end{tabular}

\section{DISCUSSION}

Based on table 1, the results were obtained that half of respondents who have moderate knowledge as many as 10 people (50\%), who have high knowledge as much as 7 people (35\%), and who have low knowledge as many as 3 people (15\%). From these figures shows that the average parent in Balong Tunjung Village has moderate knowledge, this condition can be possible because $(40 \%)$ respondents are aged 31-35 years. Because the older a person is or the older a person is, the higher the level of maturity in thinking. According to the theory put forward by Hurlock quoted by Nursalam and siti pariani (2001) the more age the level of maturity and strength of a person in will be more mature in thinking and working.

In addition, it can also be influenced by the level of education. Based on table 4.3 obtained results that almost half of respondents educated junior high school / equivalent as many as 9 respondents (45\%), who are educated in high school / equivalent as many as 5 respondents (25\%), who are educated elementary school / equivalent as many as 4 respondents $(20 \%)$, who are educated academy / college as many as 2 respondents
$(10 \%)$ and none of them don't go to school. According to Koentjaraningrat quoted by Nursalam and Pariani (2001) the higher the level of education a person becomes easier to receive information (so the more knowledge one has). On the contrary, less education will hinder the development of one's nature towards newly introduced values.

Knowledge is the result of 'knowing', and this happens after people sense a particular object. Sensing occurs through the human senses, namely: the senses of vision, hearing, smell, taste, and Touch. Most of human knowledge is obtained through the eyes and ears (Notoatmodjo, 2007). There are many factors that affect knowledge, namely education, age, occupation and environment. From the distribution of respondents based on the level of primary and upper secondary education or the level of higher education will make it easier for a person to receive better information so that it will be judged able to understand and carry out such information as well as knowledge can be improved. On the contrary low education can prevent a person from receiving better information. Based on the results of the research that has been described above, with a 
high education, a mature age and a supportive environment greatly affects the level of knowledge. But even in basic education, basic education is not inferior to higher education because the basic education often reads books and also obtains information from both television and internet media, so that basic educated knowledge is not inferior to the highly educated and it turns out that not always higher education is always dominant. most of the respondents gave APE (Educational Game Tool) as many as 13 respondents (65\%) and a small percentage did not provide APE (Educational Game Tools) as many as 7 respondents (35\%).

Educational Game Tool (APE) is a game tool that can provide optimal game functions and child development, where through this game tool children will always be able to develop their physical abilities, language, cognitive abilities, and social adaptations (Hidayat and Alimul, 2008).

Based on the facts and theories above researchers argue that almost all children are given APE and only a small percentage are not given APE this is due to the lack of knowledge of respondents about the kinds of APE itself and a small percentage of respondents are busy working so that their children are not given APE. From table 2 above shows from 20 respondents obtained half of respondents have a moderate level of knowledge as much as 10 respondents $(50 \%)$ which provided APE as many as 7 respondents $(70 \%)$ and who did not provide APE as many as 3 respondents ( $30 \%)$, who had a high level of knowledge 7 respondents (35 $\%$ ) which provided APE as many as 6 respondents (86\%) and who did not provide APE as much as 1 respondent (14\%), who had a low level of knowledge 3 respondents (15\%) who did not provide APE as many as 3 respondents $(100 \%)$ and none of them give APE.

Based on the results of the analysis to answer the research hypothesis with spearman rank test in SPSS with $\alpha=0.05$ obtained results $\rho=0.025$ ie $\rho<\alpha(0.025<0.05)$ so it can be explained that $\mathrm{H} 1$ is accepted which means that there is a relationship of the level of knowledge of parents about the function of playing with the provision of APE (Educational Game Tools) in children aged 4-6 years in Balong Tunjung Village, Benjeng Sub-district, Gresik.

Higher education, a mature age and a supportive environment greatly affect the level of knowledge. Education is a factor that greatly affects the level of knowledge. The higher the level of education of parents, the more knowledge they have about Educational Game Tools (APE). On the other hand, there is also less knowledge about Educational Game Tools (APE).

This is supported by the theory that the higher the level of education a person has the easier it is to receive information (so the more knowledge they have). On the contrary, lack of education will hinder the development of one's nature towards newly introduced values (Nursalam and Pariani, 2001).

\section{CONCLUSION}

From the results of research conducted on 20 respondents, namely in parents in Balong Tunjung Village, Benjeng Sub-district Gresik, the conclusion is that most parents who have children aged 4-6 years in Balong Tunjung Village have a moderate level of knowledge, most of the APE grants are given by parents who have children aged 4-6 years in Balong Tunjung Village. Then there is the relationship of The Level of Knowledge of Parents about the Function of Playing with the Provision of APE (Educational Game Tools) in children aged 4-6 years in Balong Tunjung Village, Benjeng District, Gresik.

\section{REFERENCES}

Hurlock, B., Elizabeth. (1997) Child Development. PT Gelora Aksara Pertama: Erlangga

Hidayat, A., Aziz Alimul. (2008). Introduction to Pediatric Nursing 1. Jakarta: Salemba Medika.

Hidayat, A., Aziz Alimul. (2003) Nursing Research and Scientific Writing Techniques. Jakarta: Salemba Medika

Hidayat, A., Aziz Alimul. (2007). Nursing Research and Scientific Writing Techniques. Jakarta: Salemba Medika.

Hidayat, A., Aziz Alimul. (2007) Nursing Research Methods and Data Analysis Techniques. Jakarta: Salemba Medika.

Ngastiyah. (2005) Sick Child Care. Jakarta: EGC.

Notoatmodjo, Soekidjo. (2005) Nursing Research Methodology. Jakarta: Sagung Seto.

Notoatmodjo, Soekidjo. (2007) Public Health Science and Arts. Jakarta: Rineka Cipta.

Nursalam. (2008) Concept and Aplication of nursing Methodeology. Jakarta: Salemba Medika.

Riyadi, Sujono., Sukarmin. (2009) Nursing Care in Children. Yogyakarta: Graha IImu.

Santrok, John W. (2007) Child Development. Jakarta: Erlangga. 
Setiadi. (2007). Concept and Application of Nursing Research. Yogyakarta: Graha IImu.

Soetjiningsih. (1995) Child Development. Jakarta: EGC

Supartini, Yupi. (2004) Teaching Book Basic Concept of Child Nursing. Jakarta: $E G C$.

Office of the Minister of State for the Role of Women in Cooperation with UNICEF. Family and Toddler Development Program Guidelines for the Use of Educational Game Tools (A.P.E.). Office of the Minister of State for the Role of Women in Cooperation with UNICEF. 